\title{
Anker Gemzøe
}

\section{Arbejderkultur i Danmark i perioden fra 1890 til 1924}

\section{Hvad er arbejderkultur?}

Skal vi forstå arbejderklassens kulturelle egenart, må vi gå ud over den snævre kultur-opfattelse, som stadig er meget almindelig, og som indskrænker kultur til borgerlig dannelse og til den ,fine“ litteratur, musik og billedkunst. I stedet må der sættes et bredt, samfundsrelateret kulturbegreb.

Inden for nyere forskning reserveres en sådan kultur-forståelse oftest til studiet af forgangne tidsaldre og såkaldte „primitive kulturer". Dog har der også - i de senere år - været en stigende interesse for dette brede, samfundsrelaterede kulturbegreb - i forbindelse med fornyet international debat om, hvad man skal forstå ved arbejderkultur, f $\phi r$ og nu. Ikke mindst fra Storbritannien og Tyskland er der kommet nye indlæg til denne debat, der - som vi skal se - iøvrigt er næsten lige så gammel som arbejderbevægelsen selv.

Raymond Williams siger f.eks. i sin bog Culture and Society fra 1963, at kultur ikke blot er kunstnerisk og intellektuelt arbejde, men en hel livsmåde, en holdning til tilværelsen, en opfattelse af hvordan samfundet er og bør være.

Den borgerlige kultur er således personcentreret, individualistisk: samfundet betragtes som et neutralt område, hvor det er ethvert individs naturlige ret frit at forfølge sin egen udvikling og sin egen fordel.

Arbejderkulturens kendetegn er derimod fællesskabet, kollektivismen: samfundet ses som et middel til kollektiv udvikling af fordele for fællesskabet. Arbejderkultur er altså ikke først og fremmest "proletarisk kunst“, men snarere den grundlæggende kollektive ide og de institutioner, tænkemåder og hensigter, der 
følger af denne. Som tyskeren Michael Vester siger det: „Hvad Goethe er for borgeren, er solidariteten for arbejderen!"

Det er vigtigt at forstå, at arbejderkultur har udviklet sig og eksisterer $i$ et klassesamfund, hvor den borgerlige kultur er dominerende. Arbejderkulturen eksisterer altså ikke i et tomrum, men må ses i sin samfundsmæssige sammenhæng, i aktiv vekselvirkning, polemik og kamp med det øvrige samfunds normer og ideer. Den er således en modkultur, der i sig rummer elementerne til et reelt, frig $\varnothing$ rende historisk alternativ for hele samfundet.

Hvorvidt disse elementer til et frigørende alternativ er mere eller mindre udfoldede, afhænger af den samfundsmæssige udvikling som helhed - men dog også mere specifikt af den opmærksomhed og bevidsthed, hvormed arbejderbevægelsen søger at beskytte og videreudvikle de forhåndenværende elementer af klassekulturen.

\section{Introduktion til perioden}

I det følgende skal jeg søge at give et signalement af arbejderkulturen i Danmark i perioden fra omkring 1890'erne til 1924. Det er et enormt omfattende emne. Alene det stof, som jeg gennem flere års arbejde har fået overblik over - og som bestemt ikke er fuldstændigt eller dækkende - går langt ud over hvad der kan formidles $\mathrm{i}$ et kort foredrag som dette. Jeg må derfor indskrænke mig til at søge at give et indtryk af enkelte udvalgte områder, som forekommer mig typiske eller centrale.

Som følge heraf må jeg også nøjes med en rent stikordsagtig skitsering af periodens almindelige historiske udvikling og arbejderbevægelsens rolle heri.

Fra 90'erne (93-94) til Første Verdenskrig var der international højkonjunktur, der fremmede en omfattende industrialisering af Danmark. Sidel $\emptyset$ bende hermed $\emptyset$ gedes den danske arbejderklasses st $\varnothing$ rrelse og betydning. Alene fra 1890-1901 steg antallet af byarbejderne fra 124.000 til 175.000. Stigningen er mest markant for de egentlige industriarbejdere, hvis antal næsten fordobles. Fagforeningerne ekspanderer og når i 1911 op på at organisere $51 \%$ af arbejderne. Det er uden sammenligning verdens højeste organisationsprocent. Arbejder-kooperationsbevæ- 
gelsen går frem, især mod slutningen af perioden - både inden for produktion og omsætning. Socialdemokratiet (SD) er i ubrudt stemmemassig fremgang. 1903 erobrer Jens Jensen finansborgmesterposten i København, få år senere bliver der socialdemokratisk flertal i Esbjerg, socialdemokratiet făr en ikke ringe indflydelse på den nye grundlov i 1915, i 1916 bliver Stauning „kontrolminister" i den radikale regering, (Nordens første arbejderminister) og i 1924-26 danner socialdemokratiet mindretalsregeringen Stauning. Forinden var der dog sket en politisk spaltning $\mathrm{i}$ arbejderbevægelsen. Allerede op til Første Verdenskrig skilte en venstrefløj sig ud, og efter den russiske revolution $\mathrm{i}$ oktober 1917 slog den internationale spaltning af arbejderbevægelsen også igennem i Danmark. Venstrefløjen var imidlertid ikke nær så stærk herhjemme som i en række andre europæiske lande.

De reelle modsætninger i denne tilsyneladende strålende udvikling kan antydes ud fra nogle markante arbejdskampe $\mathbf{i}$ begyndelsen og i slutningen af perioden.

I 1899 søgte arbejdsgiverforeningen ved en storlockout at opnå en for kapitalismen formålstjenlig regulering af strejkebevægelsen. Det kompromis (Septemberforliget), der blev resultatet af kampen, og som langt hen fremstilledes som en sejr af fagbevægelsens nydannede centralledelse, De samvirkende Fagforbund (DSF), blev begyndelsen til det særlige danske fagretslige system, der svækkede arbejdernes kampkraft, og som blev yderligere strammet ved „Normen“ (Regler for Behandling af faglig Strid) 1908 og oprettelsen af den faste voldgiftsret 1910.

1919 indførtes 8-timers-dagen, det mest fremtrædende krav for hele den internationale arbejderbevægelse i perioden. Socialdemokratiet førte forhandlingerne igennem, men det var ikke mindst syndikalisterne, der $i$ en bølge af strejker og aktioner fik fyret op under kravet og muliggjort dets gennemførelse.

1920 afværgede SD og DSF alene ved truslen om generalstrejke et højre-kup mod parlamentarismen. Men man så passivt og interesseret til, da en række strejker inden for forbund, hvor syndikalisterne havde nogen indflydelse, senere samme år blev nedkæmpet af arbejdsgiverne og deres organiserede skruebrækkerkorps „Samfundshjælpen“.

Endelig i 1925 gennemførte Dansk Arbejdsmandsforbund 
under ledelse af den socialdemokratiske folketingsmand M. C. Lyngsie den til dato mest omfattende arbejdskamp her i landet. Denne blev aktivt modarbejdet - såvel af den socialdemokratiske regering som af DSF.

- Med dette har jeg villet antyde, at der var modsætninger inden for arbejderklassen, modsætninger, der egentlig ikke blev mindre åbenbare efterhånden som arbejderbevægelsen øgede sin magt og indflydelse.

Vi skal nu se, hvorledes disse modsætninger har deres rod i arbejderklassens livssituation, og hvorledes de kommer til udtryk $i$ to forskellige udgangspunkter for en arbejderkultur.

\section{„,Spontan” arbejderkultur}

\section{Livsvilkår}

Karakteristisk er for det første den lange arbejdstid, der dog nedsættes gradvis i løbet af perioden, kulminerende med 8-timers-

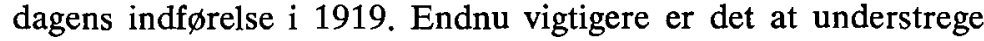
så godt som hele arbejderklassens utrygge og usikre eksistens lige op ad sultegrænsen. Der er reallønsfremgang i slutningen af 80 'erne og begyndelsen af 90'erne; derefter stagnation (moderat fremgang) til før verdenskrigen, nedgang under krigen, stor fremgang 1919-20, kraftig nedskæring fra 1921-22. Der er store lønforskelle mellem faglærte og ufaglærte - dog kan en ufaglært fabriksarbejder i visse tilfælde tjene mere end en faglært arbejder andre steder. Landarbejderne er lavtl $\varnothing$ nnede. Lavestl $\varnothing$ nnede er kvinderne, især de isolerede, uorganiserede kvinder i hjemmeindustri. En hjemmesyerske kan kun tjene halvdelen af en landarbejders årsløn.

Den hastigt voksende arbejderklasse bliver klumpet sammen i gamle udtjente boliger eller nybygget spekulationsslum (brokvartererne i København). Midt i perioden er der beregnet, at der er omkring 5,5 personer pr. lejlighed på ca. $40 \mathrm{~m}^{2}$. Hygiejnen er følgelig elendig, og syge- og dødeligheden er meget større end i andre klasser - og på landet.

Ernæringsmæssigt er det karakteristisk, at arbejderne især lever af kulhydrater og fedtstof. Protein er en luksus. Ved ar- 
bejdsl $\varnothing$ shed stiger udgifterne til grødgryn. Desuden er der kraftig forskel på ernæringens fordeling på de enkelte familiemedlemmer: manden privilegeres. I 10 ud af 22 arbejderfamilier i en lægelig unders $\varnothing$ gelse i 1880 'erne („Hobro-unders $\emptyset$ gelsen“) fik husmoder og børn aldrig pålæg på brødet, mens manden fik. Det var således ikke sult, kaloriemangel, der i de fleste tilfælde var det store problem, men systematisk fejlernæring: protein- og vitaminmangel.

Disse forhold betyder for det f $\varnothing$ rste, at den direkte $n \varnothing d$ og elendighed spiller en langt større rolle for arbejdernes tænkemåde og bevidsthedsdannelse end senere $i$ et moderne kapitalistisk samfund. For det andet giver den sammenklumpede n $\varnothing \mathrm{d}$ og utryghed $i$ arbejderkvartererne en vis basis for en umiddelbar nabosolidaritet og et nødværgefællesskab mod en fjendtlig omverden: husvært, kongens foged, politi.

\section{De to familieformer}

Ser vi imidlertid nærmere på de enkelte arbejderfamilier, viser der sig nogle markante forskelle. I virkeligheden var der to forskellige familieformer, to ret skarpt adskilte lag i arbejderklassen og følgelig to forskellige livssammenhænge.

Den følgende fremstilling af forholdene bygger jeg først og fremmest på en lang række af erindringer fra arbejdere og andre, som har haft deres opvækst eller virke $i$ arbejderklassen $i$ denne periode: Tre danske Arbejderes Livserindringer (1925), Raske Fjed (1930), Erindringer af Martin Andersen Nexø, Chr. Christensen, Anton Hansen, Peder Hedebol, Oskar Hansen, A. C. Meyer, Julius Bomholt, Ejner H. Tønnesen, Alfred Petersen, C. N. Hauge, Mikkel Christensen m.fl. Sådanne arbejdererindringer er naturligvis ikke $100 \%$ ufejlbarlige historiske kilder: der kan være digtet om, forsk $ø$ nnet, og bestemte begivenheder kan være husket forkert. Men tager man behørig hensyn til disse forhold, så er arbejdererindringerne en uvurdérlig kilde til indsigt i arbejderklassens vilkår, livsholdning og kultur.

a) De „ufaglarte“, „reservearméen"

Nogle væsentlige kilder til den fremherskende familieform i disse lag er Nexøs og Chr. Christensens erindringer, Tre danske Ar- 


\section{bejderes Livserindringer og Raske Fjed.}

Familiefaderen er ikke politisk aktiv, selv om han ofte er fagforeningsorganiseret. Han er ofte arbejdsløs eller plaget af sygdom. Familiens $\emptyset$ konomi beror på moderens og børnenes arbejde.

Faderens primære referenceramme er værtshuset. Både Chr. Christensen og Nexø beskriver deres far som intelligent og ganske afholdt blandt arbejdskammeraterne, men efterhånden (på grund af langvarig arbejdsløshed og modgang) håbløst afhængig af spiritus, hvad der sluger en stor del af $l \varnothing$ nnen. I forhold til det kammeratlige samvær på værtshusene er familien en klods om benet. Faderen er i almindelighed tilhænger af godt med prygl som opdragelsesmiddel, og $\mathrm{i}$ beruset tilstand er han $\mathrm{i}$ reglen direkte brutal over for kone og børn. Af og til udarter brutaliteten til spædbarns- og børnemishandlinger.

Moderen står som børnenes beskytter mod det faderlige uhyre. Hun har talrige konfrontationer med manden uden at det hjælper synderligt og uden at blive i stand til at bryde med ham. Med vekslende ude- og hjemmearbejde slider hun for at klare dagen og vejen for sig og børnene (og delvis også for manden). Stadige graviditeter, aborter, stor børnedødelighed og -sygelighed præger hendes tilværelse.

Drengene nærer frygt og efterhånden had til faderen, der $\mathrm{i}$ Nexøs og Chr. Christensens tilfælde kulminerer i fysiske opgør, da de er stærke nok. Fra børnene er 3-4 år inddrages de til pasning af mindre søskende eller hjemmeindustri.

Børnenes „socialisation“ fører således frem til en udpræget kærlighed til moderen og et had til faderen, der på en vis måde fremstår som de ydre autoriteters, voldens og undertrykkelsens indbrud i familien. Faderhadet kan således (af de nævnte sociale grunde) fungere som katalysator for et generelt autoritetshad. Dette gælder især for drengene.

Typisk for hele familien er en fremmedhed og/eller modvilje over for skolen, kirken og den borgerlige kultur.

En ekstrem, men ganske udbredt variant af denne familieform er den faderløse familie. En stor del af arbejderkvinderne i Raske Fjed ender med at skulle fors $\varnothing$ rge en b $\varnothing$ rneflok selv.

Af stor betydning for disse familiers overlevelse er den f $\varnothing \mathrm{r}-$ nævnte umiddelbare nabo- og kvartersolidaritet. 


\section{b) De "faglcerte"}

Karekteristikken af denne familieform bygger bl.a. på erindringer af Oskar Hansen, Bomholt, A. C. Meyer og Anton Hansen. Det må understreges, at familieformen ikke blot er almindelig for de egentlige faglærte arbejdere, men $i$ det hele taget for arbejderklassens mere socialt stabile lag.

Faderen er ofte politisk eller fagforeningsmæssigt aktiv. Han står for familiens $\varnothing$ konomi. Moderen er, eller bliver efter nogen tid, hjemmegående husmoder.

Faderen går meget op $\mathrm{i}$ børnenes opdragelse og udviser ikke vold og brutalitet. Han kommer derfor i nogen grad til at stå som eksempel, som ideal, for sønnerne. Moderen har mulighed for at sørge for, at hjemmet præges af anstændighed, orden og pænhed.

Det foreningsliv, som faderen deltager $\mathrm{i}$, kan foregå i tilknytning til parti, fagbevægelse, sangforeninger eller arbejdersport. I visse tilfælde inddrages også moderen og familien (f.eks. til friluftsm $\varnothing$ der, sangforeningsudflugter o.1.) Forældrene kan også deltage $i$ arbejderoplysende undervisning, de kan meget vel have interesse for naturen og har $\mathrm{i}$ reglen et positivt forhold til (dele af) den borgerlige kultur.

De har derfor også en positiv holdning til skolen og hjælper efter evne børnene til at hævde sig i konkurrencen.

Solidaritet er for disse familier ikke primært knyttet til naboskabet og kvarteret, men til foreningerne og den organiserede arbejderbevægelse.

Det er disse lag $\mathrm{i}$ arbejderklassen - og dermed denne sidste familieform - der bliver det helt dominerende udgangspunkt for den „organiserede“ arbejderkultur. Men herved skubbes den radikale solidaritet, det radikale antiautoritetselement og den radikale mistro til den borgerlige uddannelse og kultur i baggrunden og fortrænges. Det er på denne måde de næunte lags dominans sætter sig igennem på det kulturelle område. 


\section{„,Organiseret” arbejderkultur}

\section{Fagbevagelsen}

Fagbevægelsen spiller en hovedrolle $\mathrm{i}$ disciplineringen og formningen af arbejdermassernes bevidsthed. Inden for fagbevægelsen tager solidariteten form af en anti-skruebrækker-ideologi.

For de enkelte fagforeninger var det et spørgsmål om overlevelse at få hamret denne ideologi ind i medlemmerne og på arbejdspladserne $\mathrm{i}$ det hele taget. Intet under at man var knaldhårde $\mathrm{på} \mathrm{dette} \mathrm{punkt} \mathrm{og}$ tog alle midler $\mathrm{i}$ anvendelse. I Erik Christensens bog om Havnearbejderstrejken $i$ Esbjerg $i$ 1893 (SFAH nr. 2) gøres der overbevisende rede for uforsonligheden over for skruebrækkerne, „forræderne“. Og i hele fagpressen havde man en fast rubrik med overskriften „Sløjhedens Protokol"; heri udhængtes med navns nævnelse og portræt de lede skruebrækkere - eller folk som blot havde undladt at betale fagforeningskontingent.

I $\varnothing v$ rigt fungerer fagbladene i 80 'erne og 90 'erne i h $\phi \mathrm{j}$ grad som kommunikationskanaler for medlemmerne selv. Først efter århundredskiftet slår fagbevægelsens centralisering også igennem i bladene som énvejskommunikation fra ledelsen til medlemmerne.

Fagbevægelsens organiserede manifestationsformer - strejken, demonstrationen, folkem $\varnothing$ det og generalforsamlingen - er ligeså mange nye former for kollektivt samvær. Bomholt skriver i Arbejderkultur, at arbejderkulturen i sin „første fase“ nåede sit højeste udtryk i demonstrationen: som fest- og kampprocession fungerede den som "Gesamtkunstwerk". Hvorledes forskellige modstridende tendenser kunne komme til udtryk i forbindelse hermed, kan anskueliggøres ved en samtidig kommentar (en billedtekst i Social-Demokraten, Århus) til 1. maj-demonstrationen 1899 i Ârhus, hvor processionen beskrives således: „Den drager med flyvende Faner og klingende Spil gennem Byens Hovedgade. I Storborgerhusenes Vinduer er der fuldt af Nysgerrige, men selv den reaktionæreste Spidsborger maa fyldes af Respekt for den Orden og Værdighed, hvormed Arbejderne demonstrerer." Altså på den ene side en magtdemonstration, på den anden side en demonstration af respekt for spidsborgerlige normer om orden og pænhed. 


\section{Partiet (Socialdemokratiet)}

Udover de aktivitetsformer, der er fælles med fagbevægelsen, virker partiet kulturelt især ved partiskoling, arbejderoplysning og agitation. Et af de vigtigste instrumenter for partiskolingen var de socialdemokratiske diskussionsklubber, med Diskussionsklubben „Karl Marx“ - oprettet 1886 på foranledning af A. C. Meyer - som gallionsfigur. Her skolede intellektuelle og arbejdere hinanden med det korte oplæg og den frie debat som pædagogisk metode. Her blev der holdt et vist liv i den teoretiske debat. Og herfra rekrutteredes $i$ vid udstrækning partiets tillidsfolk og agitatorer. Som et supplement til partiets dagspresse og bogserier (bl.a. Socialistisk Bibliothek og Socialistiske Skrifter) udgav også diskussionsklubberne tidsskrifter, således det mere teoretisk prægede tidsskrift Socialisten.

Partiet som kulturfaktor, som underholdning og oplysning, mødte arbejderne $\mathrm{i}$ denne periode (f $\varnothing \mathrm{r}$ radioen) $\mathrm{i}$ agitatorens skikkelse. I Vinterlys, bind 2 af sine erindringer, har Julius Bomholt givet en selvoplevet skildring af, hvorledes Socialdemokratiets ber $\varnothing$ mteste agitator, arbejderdigteren A. C. Meyer, holder foredrag i Silkeborgs nordlige arbejderforstad om den store franske revolution.

Beskrivelsen virker så overbevisende, at et længere citat må være berettiget:

- Ja, så begynder vi.

A. C. begyndte lavt og stilfærdigt med at sige tak til de mennesker, der var mødt.

- Flyt jer blot lidt nærmere sammen, sagde han, for det, jeg skal fortælle om i dag, er noget om det gode kammeratskab. „Ryk tættere sammen“, hedder mit foredrag.

Det kostede en tids overvejelser og megen overvindelse at finde sammen på anden og tredie bænk. Den første bænk var der ingen, der ville sidde på.

- Jeg trækker en pistol op af lommen, spænder hanen og affyrer et skud i hovedet på den nærmeste, - for det er velsagtens sådan, I forestiller jer revolutionen - sådan begyndte han. - Men ser I - revolution er i virkeligheden noget andet end bål og barrikader. Den er et liv, der fødes ... Ja, jeg burde 
tage drengen dér (og han pegede på mig) ved hånden og stille ham op på bordet og sige: her er revolutionen!

Jeg kunne have krøbet ned imellem gulvbrædderne, bort fra de ansigter, der skottede efter mig.

- Den store franske revolution, sagde han, - det var mennesket selv, der rejste sig og krævede menneskeret. Mennesket vor bror. Det blev m $\phi d t$ med vold og værgede sig, og selv i den vildeste kamp på barrikaden lød råbet: vi kæmper også for jer, der vil myrde os, vi kæmper for alles ret til at være.

Hans stemme virkede til en begyndelse noget tynd og flad. Vi var ikke fortrolige med denne københavnermåde at tale på. Men hvert ord blev forstået, og efterhånden var der noget, der var stærkere end de ydre ord. Det ene syn steg frem bag det andet. Det lille bord, som han støttede sig til, forsvandt, og væggen bag ham veg til side for dybe og skønne billeder. Han talte billeder ind $\mathrm{i}$ os.

Vi så mennesker komme myldrende ud af deres skumle huse. De fattige ville være herre i deres egen gade. Frihed! råbte de. Alle menneskers frihed! ... Den grå bastille sank om i grus og flammer.

Og så var det hundrede år senere. Paris var en by $\mathrm{i}$ jubel. Der var dans på torvet $\mathrm{i}$ den lyse julinat foran rådhuset, og A. C. var til stede som udsending for de danske arbejdere ...

Det mørke, vemodige ansigt med de brede kinder og de fanatisk sorte lokker blev ligesom omgivet af et halvvejs synligt skær af faner og fakler. Parisernatten dansede omkring ham.

- Trumf es! lød en stemme fra sideværelset. Der var nok efterhånden gået feber $\mathrm{i}$ spillet derinde ... Men A. C. lod sig ikke forstyrre. Han fik hundredårsfesten til at leve. Tillidsmænd fra alverdens lande mødtes og vedtog, at første maj skulle være alle arbejderes fælles festdag. Der skulle demonstreres for 8 timers dagen, for samarbejde og fred. Og aitsammen: for menneskets skyld. En verden i vold skulle forandres til en verden i menneskelighed.

Og nu I! - Hans zigeunersorte фjne, der midt $\mathrm{i}$ ordenes syner bevarede dette skær af melankoli, betragtede os. Også $I$ har en plads i et fællesskab, der rakker ud over jorden. Verden er een, og vi skal gøre den til arbejdets frie verden. 
Måske ser I kun jeres egen hverdag og jeres egne pjalter, og måske synes $\mathrm{I}$, at I er spærret inde $\mathrm{i}$ en grå bastille ...

Han skildrede livet $\mathrm{i}$ vore egne stuer, de daglige skærmydsler, - som om han personligt havde været indenfor dørene og set det hele, - en kæde af vemodige billeder, - og enkelte lyse glimt - og midt i skildringen kom kortspillerne ind og stillede sig lyttende opad vaggen mellem døren og kakkelovnen. Her var noget, som var stærkere end selv et spil med trumf i hjerter.

A. C. fortalte om det arbejde, der nu blev gjort for at frigøre mennesker fra nød og sult. Alle linjer $i$ dette arbejde pegede fremover - opover - mod en lysere verden, og skulle vi nå den, var det nødvendigt, at arbejderne selv tog fat og selv gik i spidsen.

Og lidt efter lidt fik billedet en dybere dimension. Fremtidens land stod frem for vore øjne - og jeg var sikker på, at selv de mænd, der endnu sad foroverludende og lod blikket være rettet mod gulvet, så det. Vi alle så det. Bjerget, som løftede sig op imod en lysfyldt himmel, - en sommerhimmel, - og det lange tog af mennesker, som vovede at bestige det.

Det var unge arbejdere, der gik forrest, og allerforrest gik en fløjtespiller, der bare glædede sig over sit spil; han vidste ikke af det, og alligevel var det, som om hans spil fik smilet til at vokse overalt. De unge piger lo. En moder løftede sit barn mod solen. Og se! - dér kom arbejdere med deres eneste våben: deres spader, der glimtede i lyset. Gamle mænd og gamle koner fulgte med, og unge og gamle tog hinanden $i$ hånden. De steg opad mod de frie vidder. Mod en ny tids sol. Frihedens. Livets. Alskabningens sol.

Til sidst var det, som om ordene blev borte og kun synet levede. $\AA$ h, jeg så, hvorledes det lange tog af mennesker, aile i træsko, - træskofolket -, blev ved at vandre. Opover. Opover.

Hvornår sluttede talen? Syn og tone blev ved at leve $\mathrm{i}$ vore sind. Vi blev siddende. Tavse. Ingen havde trang til at bryde den sære højtid.

Men noget måtte jo ske.

- Hvis nogen har lyst til at købe min sidste bog -, sagde A. C. og pakkede den kardusgrå pakke ud og nævnede en pris. Men der var ingen, der købte. 
Mads Nielsen rejste sig. Vi ventede vistnok allesammen, at han skulle sige et par ord til slut, men han rettede benene og gik hen til yderdøren og kiggede efter vejret.

„Skytten" sendte harkende en klat i retning af en spytbakke, der stod ved siden af kakkelovnen. - Det er altsammen meget kønt, brummede han, - men hvor satan går vi hen og får arbejde.

Det gik efterhånden op for os, at der var lige så koldt $\mathrm{i}$ salen, som da foredraget begyndte. Jens Roed og Grønvald og flere andre gik hen og gav A. C. hånd - og trak sig tilbage.

Til sidst var der ikke andre end A. C. og far og jeg tilbage i salen.

- Hvis du vil følge med hjem, sagde far, - ja, jeg ved ikke, om du har fået noget at spise.

- Ikke siden i morges.

- Jeg er ikke sikker på, at vi kan byde på andet end kaffe. Vinterlys, p. 139-41.

\section{Arbejderoplysning}

Agitatorens lyrisk-visionære reformisme blev fulgt op af de mere prosaiske aktiviteter, der kan puttes ind under samlebetegnelsen: arbejderoplysning. De første former for arbejderoplysning i stort format - Studentersamfundets Aftenundervisning, Folkeuniversitetet og visse af læseselskaberne - var uden for partiets kontrol og lededes af venstreborgerlige akademikere og studenter. Men efterhånden udfoldedes der $\mathrm{i}$ arbejderbevægelsens regi et kolossalt arbejde på dette område, med oprettelsen af Esbjerg Arbejderhøjskole 1910 og Arbejdernes Oplysnings-Forbund 1924 som højdepunkter.

I denne sammenhæng kan jeg imidlertid ikke komme nærmere ind på arbejderoplysningen og dens historie. Bare at skitsere hovedlinjerne kræver megen tid og plads.

\section{Vandre- og ungdomsbevagelse, sport}

Arbejderbevægelsen gik også ind i sporten. Igen med A. C. Meyer som medinitiativtager oprettedes Kjфbenhavns Athletklub. Senere oprettede en lang række fag sportsklubber, Typografernes 
Boldklub osv. Sportsklubberne fremmede samværet mellem arbejdskammerater uden for arbejdstiden - og dermed solidariteten. En bevidst sportspolitik i opposition til den borgerlige form for sportsud $\varnothing$ velse synes dog f $\varnothing$ rst at være under udvikling efter Første Verdenskrig, da den danske arbejdersport blev tilknyttet Arbejder-Sport-Internationale.

I forhold til børne-, ungdoms- og vandrebevægelsen søgte man at skabe et alternativ til de borgerlige spejderkorps ved oprettelsen af De Unges Idrat.

\section{Arbejdersangen}

Sangen er den kulturelle aktivitet i snæver forstand som tidligst blev taget systematisk op af arbejderbevægelsen - og som fik den bredeste udfoldelse.

Sangen har som medium den fordel, at den kan indgå organisk i arbejderbevægelsens samværsformer, således enhver art af $\mathrm{m} \phi$ der, forsamlinger og demonstrationer. Som Oluf Bertolt siger det i artiklen Arbejdersang (tidsskriftet Arbejderhфjskolen): „Arbejdersang er det som Arbejderne synger - subsidiært burde synge - i Fællesskab, når de optræder som et Kollektiv.“

Den danske arbejdersangs udvikling $\mathrm{i}$ den her omhandlede periode kan kort skitseres ved en skematisk udskillelse af fire forfatter-,generationer“ - samt ved en fremhævelse af de væsentligste sangb $\emptyset$ ger.

Den første og st $\varnothing$ rste gruppe af sangforfattere er knyttet til Internationale i begyndelsen af 1870 'erne. Det er folk som Toucher, Alfr. J $\varnothing$ rgensen, Saxo Wiegell, Fr. Hertz og U. P. Overby. Den sidste er den kendteste, bl.a. forfatter af Socialistmarchen (,Snart dages det, Brødre ..."). Som karakteristisk eksempel for denne generation tager jeg en anden af U.P. Overbys sange:

\section{Proletarernes Vise}

Enhver som har traadt sine B $\varnothing$ rnesko

Med barkede Næver på Skaft,

Med fribaarne Tanker og egen Tro,

Han ejer en sælsom Kraft; 
Naar Arbejdet vinker ved Morgengry, Naar Friheden krænkes ved Krudt og Bly, Saa er han paa Gaden

Og midt i Balladen

Ved Haanden med Raad og til Daad.

Det Barn, som blev født i en pjaltet Klud Og ammet ved Ulykkens Barm,

Kan haanes og hades og grines ud, Men dog faa en kraftig Arm;

Naar Sulten og Kulden det hærdet har,

Saa voxer det op til en Proletar -

At han skulde være

Jert Samfund til Ære -

Det kan I ej vente af ham.

I kuede tidlig en kraftig Aand

Og I vilde knuse hans Mod, Saa ofte han gav Eder Broderhaand, Forgiftede I hans Blod -

I har forurettet ham for en Stund

Og klippet hans Pels som en Puddelhund $\mathrm{Nu}$ haandhæves Retten, Han m $\varnothing$ der paa Pletten

I straalende Solskins Humør.

Forandret lyder „Signalernes“ Klang!

Nu kommer de Mange og Smaa, Marschen gaar fremad til Arbejdersang, Det kunne I stole paa. -

Vi har en Høne at plukke i Mente, Der er baade Renter og Renters Rente Til Eder paa Gaden, Naar midt i Balladen

Vort Regnskab vi opgjøre skal.

I denne sang tages der klart udgangspunkt i proletatiatet som en klasse, der er totalt udstødt af "samfundet", og hvis perspektiv derfor ikke er reformer, men en radikal omvæltning af det be- 
stående. Udgangspunktet er således de lag i arbejderklassen, som jeg har karakteriseret som „de ufaglærte“ - og i deres familie (opløsnings-)form.

Disse første sange kom i begyndelsen af 70'erne som skillingstryk; man udnyttede på denne måde de populære skillingsvisers distributionsform. I $1876 \mathrm{kom}$ den første sangbog, der i 1886 udvidedes til den 478 sider store Sangbog for Socialdemokratiske Arbejdere.

I denne træder den danske arbejdersangs „anden generation“ frem med S. Kjeldskov. Det er i 80'erne, fagbevægelsens store opbygningstid, hvor de faglærte afgørende knæsætter deres dominans $i$ arbejderbevægelsen. Som et indholdsmæssigt dakkende eksempel - også for sangene - kan vi tage slutningen af et digt af Kjeldskov: Smedens Dr $\phi m$.

Det var en uhyggelig drøm, hvor svendene efter en tabt lockout må vende tilbage til arbejdet og udholde skruebrakkernes hån og spot og som retsløse tåle mesters uindskrænkede tyranni over lø̄n- og arbejdsforhold. Bleg som et lig slår svenden mester til jorden med den store hammer - og vågner:

Det var kun en Drøm! Jeg var glad igen, thi Slavelænken var bristet.

Jeg var atter den samme frejdige Svend

og havde ej Friheden mistet.

End stod vort Forbund urokkelig fast, og jeg i de Kæmpendes Rækker; endnu vort Sammenhold ikke brast, ej Vingen man paa os stækker. End strider vi sammen som Mænd til Værn mod Storborgerbladenes L $\emptyset g n e$, og Sejren, ved vi, er ikke fjærn; den gryende Dag alt vi øjne.

Jeg svor ved mig selv en hellig Ed:

F $\phi r$ I mig $i$ Graven lagger, for Jer Kammerat skal synke ned til at blive en Skruebrakker.

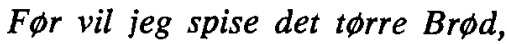
før jeg Tral for min Mester vil vare, 
og heller jeg sulter og lider $N \phi d$, end jeg salger min Frihed og AEre!

Som det ses er udgangspunktet her et andet: solidariteten er knyttet til den organiserede arbejderbevægelse, den tager form af en anti-skruebrækker-ideologi og den knytter an til håndværker-traditionerne for frihed og uafhængighed.

Arbejdersangens "tredje generation" personificeres af A.C. Meyer og Edvard Søderberg. A. C. Meyer bliver den danske skjald for Anden Internationales klassiske reformisme. Første og sidste strofe fra Majsangen (1892) kan give et indtryk af tonen og indholdet:

Faldne er nu Vintrens sidste Skranker, Broder, Du maa ud at sole Dig! Tusinder af kække Hjærter banker imod dit, i Dag, den første Maj. Verdens Ungdom smykker sig i Haabet under Vaarens lysegrønne Tag, og mod ranet Rigdom stiger Raabet om den 8 Timers Arbejdsdag. […] Ret nu Ryggen, [Bro'er], løft Blikket, Søster! ved I ikke, det er Eders Tur? Har I glemt, at I har stærke Røster? Lovsyng da den vaagnende Natur. Lige Tid til Arbejd og til Hvile og til Kamp for Livets unge Sag; første Maal, hvorhen Jer Kraft maa stile, er den 8 Timers Arbejdsdag!

En anden karakteristisk lyriker og sangforfatter er Edvard Søderberg, hvis bog Gadens Digte (1900) blev meget populær. Herfra stammer den kendte sang I Danmark. De første og de sidste strofer lyder således:

I Danmark ligger der Hus ved Hus, vel tusind smaa Huse paa Rad, med røde Tage og Skorstensrøg, 
der dufter af Middagsmad.

Vel tusind smaa Haver med Blomsterbed, hvor Levkøjer og Asters gror -

Kirketaarne bag Bakkehæld og bittesmå Sejl over Fjord. $[\cdots]$

Jeg elsker det Folk, de tusinde Smaa, som i Danmark bygger og bor Fattigmands Rønne ved Alfarvej og Fiskerbaaden i Fjord.

- De tusinde Smaa, der stedes i Strid og vinder kun Fod for Fod Spe over dem, der vil Folket tillivs og kue og knægte dets Mod!

Det er de tusind små hjem og det fattige, men pæne småborgerskab, der nu begynder at slutte op i socialdemokratiets rækker og præge dets forestillinger.

I århundredets første tiår udvikler landarbejder-, tyende- og husmandsbevægelserne deres egen sangtradition med bl.a. Skjoldborgs og Aakjærs sange.

Den sidste "store“ generation af egentlige danske arbejdersangforfattere er knyttet til SUF og venstreoppositionen omkring 1. verdenskrig. Nogle hovedrepræsentanter er Mikkel Christensen og Oskar Hansen. Som et eksempel på den fornyelse de repræsenterer kan peges på Oskar Hansens Ung Flagsang („Naar jeg ser et rødt Flag smelde").

SUF udgav allerede i 1910 deres egen sangbog, sammen med Sangbog for socialdemokratiske Arbejdere fra 1886 den bedste danske arbejdersangbog.

Også i 1910 kom Esbjerg Arbejderh øjskoles sangbog, hvor Aakjærs natursange - samt en hel del af højskole-sangtraditionen (Grundtvig, Ingemann m.v.) - vandt indpas. Dette eskalerede med AOFs Arbejdersangbogen (1924), hvor over halvdelen af sangene er i højskoletraditionen og hvor der således sker en voldsom forrykning af sangtraditionen og dens klassetilknytning. Venstreoppositionen udgiver ganske vist også deres sangbøger, 
således FS i 1918 og DKP med Revolutionar Sangbog i 1928. Men hovedindholdet er her oversatte sange, der ikke har nogen umiddelbar tilknytning til den danske klassekamp og den danske arbejderklasses erfaringer. Endvidere karakteriseres de ved, at deres "radikalitet" ofte kommer til udtryk gennem en krigeriskfeudal metaforik: det vrimler med spyd, sværd, skjolde og hjelme. Inden for arbejdersangen lykkedes det således ikke for denne venstreopposition at skabe noget egentligt alternativ, nogen egentlig fornyelse.

Allerede i 70'erne dannedes Sangforeninger som Lanternen og Den røde Stjarne. At dømme efter Socialdemokratisk Sangbog, som blev udgivet 1886 af Den sociale Arbejder-Sangforening for Slagelse og Omegn bestod sangforeningernes repertoire endnu i 80'erne af de „klassiske“ arbejdersange.

Ud fra senere jubilæumsskrifter (f.eks. ved 50-årsjubilæet for Kularbejdernes Sangforening) får man imidlertid indtryk af et repertoire helt præget af borgerlig skønsang og en form for optræden, der nærmest synes at skulle negere og kompensere for sangforeningsbrødrenes proletariske oprindelse: alle optræder if $\varnothing$ rt kjole og hvidt!

Der var da også folk, som efterhånden mente, at arbejdersangforeningerne snarest havde en negativ virkning på arbejdersangen. Således skrev Marinus Christensen i en artikel i SUFs blad Fremad, nr. 17, 1910 Syng vore Sange:

„Sangforeninger i Hobetal har skabt en Art tvivlsom Kunst, men de er godt paa Vej til at dræbe Folkesangen. Tonerne skal være saa fine og rene, at en almindelig dødelig næppe vover at synge mere“.

\section{Arbejderlitteratur}

I denne sammenhæng må jeg indskrænke mig til en yderst kortfattet og skematisk oversigt over arbejderlitteraturen, dvs. romaner, fortællinger og noveller, som forholder sig til arbejderklassen og/eller -bevægelsen.

Ved „arbejderlitteratur“ vil jeg i $\emptyset$ vrigt forstå litteratur, der på forskellig måde og i forskelligt omfang indgår i den stadige 
kamp for arbejderklassens konstituering som en interessebevidst klasse-for-sig.

Den litteratur, der normalt regnes for den tidligste danske arbejderlitteratur og som især blomstrede $\mathrm{i}$ dette århundredes første tiår, bærer derfor ifølge ovenstående definition en forkert betegnelse. Det er en småborgerlig rædselsrealisme, hvis emne er den pittoreske eller medynkvækkende elendighed $i$ arbejderklassens mest udsatte lag, men med forkærlighed i pjalteproletariatet. Disse „forbryderromaner“ („Halvmennesker”, „Spild”, osv.) er i bedste tilfælde symptomer på, at repræsentanter for andre klasser havde opdaget et "problem“.

De første eksempler på en virkelig arbejderlitteratur kommer - i det stadig landbrugsdominerede Danmark - med Skjoldborgs landarbejderroman Gyldholm (1902) og Aakjærs tyenderoman Vredens B Brn (1904).

Det egentlige litterære udtryk for periodens arbejderbevægelse - der med en usædvanlig prægnans blotter den danske og i vidt omfang også den internationale arbejderbevægelses storhed og begrænsninger - er Nexøs forfatterskab, især Pelle Erobreren I-IV (1906-10), novellesamlingen Af Dybets Lovsang (1908) og Ditte Menneskebarn I-V (1917-22).

At gå indholdsmæssigt ind på arbejderlitteraturen er som sagt umuligt i denne sammenhæng, men jeg vil med et enkelt eksempel berøre et andet forhold: arbejderlitteraturens tilegnelsesformer. På tobaksfabrikken C. W. Obel i Aalborg var det fra tidligt i århundredet og helt op til 1959 tradition, at håndrullerne (der jo længe var den største gruppe af tobaksarbejdere) skillingede sammen og betalte en kammerat eller en arbejderforfatter for at læse op for dem en halv til en hel time om dagen, mens de arbejdede. Det vil være væsentligt at unders $\emptyset$ ge, hvor udbredt kollektive „fabriksnære“ og proletariske tilegnelsesformer som denne har været.

\section{Arbejderbevægelsens kulturpolitik}

I de overordnede kulturdebatter inden for arbejderbevægelsen, der begyndte at komme igang i periodens løb, kan der udskilles tre hovedsynspunkter: det moderate, det radikale og det „anarkistiske“. 


\section{Det moderate synspunkt}

Det kom klarest og mest udfoldet til udtryk i K. K. Steinckes lange artikel Kulturbetragtninger, der i småbidder blev trykt i Socialisten fra juni 1911 til maj 1912.

Artiklens første del består af betragtninger over kulturbegrebet og såkaldt „materiel“ kultur. Her fremstiller Steincke også sin klassisk revisionistiske kapitalisme- og socialismeforståelse. Han ser således frem til, „at Privatkapitalismen, der har løst Produktionsspørgsmaalet, efterhaanden afløses af Socialismen, der ogsaa formaar at løse Fordelingssp $\varnothing$ rgsmaalet“.

Anden del omhandler den „personlige Kultur“, og det er her Steinckes egentlige engagement ligger. Arbejderbevægelsen har, mener han, på ingen måde gjort nok for at udvikle det enkelte individs personlige kultur og dannelse. Især anklager han Socialdemokratiet for at have svigtet afgørende på to punkter:

For det første er Socialdemokratiet (ikke mindst den socialdemokratiske presse) ikke frisindet og tolerant nok. Arbejderbevægelsen burde være præget af respekt for andres (borgerlige osv.) mening, af holdningsrelativisme og tolerance. I stedet har socialdemokratiet snarest gjort arbejderne „intolerante“ og „ensidige".

For det andet har Socialdemokratiet næsten overtaget det degenererede, udsvævende borgerskabs syn på ægteskabet og kønslivet, altså taget den brandesianske radikalismes "Livsanskuelse grundet paa Elskov" til sig. Man rakker ned på „selve Institutionen: Ægteskabet, Hjemmet“, og der er endog nogle, der lufter tanker om en samfundsmæssigg ørelse og kollektivisering af børneopdragelsen. Steincke er rystet: „Gud fri og bevare os for „kasernemæssig“ Børneopdragelse. - Nej, ligesom Forbindelsen mellem een Mand og een Kvinde er den moralske Hovedregel, således vil Ægteskabet og Forældrenes Samliv med Børnene, kort sagt de gode Hjem stadig blive Grundvolden for et hensigtsmæssigt ordnet Samfund".

For Steincke er den egentlige kultur den, der udfolder sig omkring privatsfæren, fritiden og personligheden. Inden for disse uanfægtede rammer ser han det som socialdemokratiets opgave at indpode arbejderne småborgerlige normer og moral. 


\section{Det radikale synspunkt}

Herbert Iversens foredrag Om socialistisk Kultur, der blev trykt i Socialisten fra juli til september 1913, er én stor polemik med Steinckes betragtninger. If $\varnothing l g e$ Herbert Iversen er det arbejderbevægelsens opgave at fremme og styrke opbygningen af en særlig arbejderkultur, hvis grundpiller må være materialismen og det sociale synspunkt. Den følgende citatrække viser hans måde at stille problemet på:

"I ethvert Klassesamfund vil det ifølge Marx være saaledes, at den herskende Klasses materielle interesser dikterer denne Klasse dens aandelige Kultur og Moral, som den saa søger at paatvinge de undertrykte Klasser".

„Men [...] når der indtræder en Klassekamp, da vil der samtidig indtræde en Kulturkamp".

- I klassekampen har proletariatet overtaget „en ny $K u l$ turform, nemlig den socialistiske, hvis særlige Kendetegn altsaa er et udpræget materialistisk og et udpræget socialt Syn på Menneskelivet. Vi staar midt i en Kulturkamp, hvor det galder at slaa Overklassens gamle Aandsform ned og fremme vor egen".

„Her er Tale om en Overgangstid, en social Revolutionstid, hvor to fjendtlige Produktionsformer slaas paa Liv og D $\phi \mathrm{d}-$ og dermed to fjendtlige Kulturer - og da siger jeg: saalænge den gamle liberale Kultur raader over Masserne, og de ikke er socialistisk oplyste, saalænge er det ikke raadeligt at bygge den socialistiske Samfundsmagt paa dem.

Og her staar jeg da ved det Spørgsmål, der vel sagtens særlig vil bære Diskussionen i Aften: $E r$ vi - i det danske Socialdemokrati - os den dybe Forskel bevidste, der er mellem socialistisk og liberal Kultur? Og havder vi os nok overfor den liberale Kultur? Jeg kan straks sige, at det er mit Indtryk, at vi ikke er det og ikke gør det - i Forhold til vor materielle Magtstilling".

Med udgangspunkt i „Nutidsmoralen i den danske Arbejderklasses daglige Liv“ søger Iversen derefter at anskueligg $\emptyset r e$, hvorledes man ser „Begreber om godt og ondt aflejrede fra 
højst forskellige Tider og Samfundsformer": „endnu er Arbejderne fyldt med Feudalisme og Liberalisme". Kun en konsekvent socialistisk kulturkamp kan frigøre og opfølge klassekampens praktiske oplæring af arbejderklassen i materialisme og solidaritet.

Iversen gennemgår nu en række af det borgerlige samfunds „kulturelle“" undertrykkelsesinstitutioner (og søger i den forbindelse at opstille delmål for kulturkampen): kirken, pressen (hvor han retter en ganske anden kritik mod den socialdemokratiske presse end Steinckes), litteraturen (hvor han temmelig overlegent afviser Aakjær, Skjoldborg og Nex $\varnothing$ ), teatret og filmen, ugebladene og arkitekturen. Foredraget slutter med et generalangreb på den borgerlige individualismes forfinede klagetoner og æteriske kultursuk. Den slags skal man ikke lade sig forbløffe af, siger han:

„Vi har nu brug for tungtbevæbnede og uforsonlige Mænd, der ikke lader sig forbløffe“.

„Denne store Omvurdering - $i$ materialistisk og social Aand - er det vor Opgave at gennemføre trods de gamle Kulturers Vardibegreber, der strider herimod. Gennemsyre Masserne med den socialistiske Kultur, uden hvilken et socialistisk Samfund ikke kan sikres, og saa gennem sindrigt og velorganiseret Samarbejde dyrke vor gode jordiske Planet og fremme Broderskabet mellem alle Mennesker.

Denne Opgave løser Arbejderklassen kun gennem Magt, hvilende paa Selvhævdelse og Selvtillid, og den har ingen andre at tage Hensyn til under Kampen end sig selv."

En yderligere dimension får det „radikale“ synspunkt i E. Jensens artikel Arbejderne og Teknikken (trykt i Socialisten nr. 3, 1911) der er bemærkelsesværdig ved at angribe den borgerlige kulturs samfundsmæssige grundlag: undertrykkelsen i produktionen, det borgerlige vidensmonopol, arbejdsdelingen mellem håndens og åndens arbejde. Heroverfor sætter E. Jensen et omvæltningsperspektiv, der stiller Steinckes opfattelse af, at kapitalismen har løst „Produktionsspørgsmaalet“, grelt i relief: 
- „... naar et Arbejde - det være sig nok saa kedeligt og aandsfortærende - er nфdvendigt for Samfundets Bestaaen og Velvære, saa burde det være en Ære for alle Samfundets Medlemmer at hjælpe med i Stedet for at sky det. Naar derfor Arbejdet fordeles paa mange Hænder eller skiftevis forrettes af den ene efter den anden, saa kan de $\emptyset v$ rige Individer hengive sig til andre interessante eller belærende Beskæftigelser, og naar alle har haft Lejlighed til at føle Aaget, saa vil alle, eller $\mathrm{i}$ alt Fald mange flere end nu, anspores til at fjerne Ubehagelighederne og søge Lettelser.“

For at fremme og forberede ophævelsen af arbejdsdelingen mellem håndens og åndens arbejde må arbejderne allerede $\mathrm{i}$ dag søge at højne deres tekniske viden. Og de må vel at mærke gøre det selv, da de eksisterende institutioner - tekniske skoler m.v. - er indrettet på at kvalificere til bestemte poster $\mathrm{i}$ det arbejdsdelte klassesamfund.

„Det er ligesaadan med vore Skoler for Børn og Unge Mennesker. Sædvanlige Kommuneskoler, Mellemskoler, Realskoler, Gymnasier, Forberedelsesskoler, Latinskoler, Læreanstalter, Akademier, Kursus'er, og hvad de alle hedder, baserer alle paa at bringe Kundskaber i visse Kvantiteter, afmaalt efter Stand og Klasse."

„Med andre ord: Arbejderne bør selv være sine egne Teknikere, sine egne Ingeniører."

Som et egnet middel til at fremme dette mål, arbejderklassens reelle beherskelse af produktionsprocessen, anbefaler E. Jensen, at arbejderbevægelsen opbygger sin egen tekniske presse. Dette projekt sættes ind i en st $\varnothing$ rre sammenhæng, nemlig en kamp for at opnå vidensmæssigt og kulturelt hegemoni:

„Hvad der navnlig er væsentligt, er, at Arbejderen dermed kommer til at snakke med for Offentligheden $i$ alle tekniske Anliggender.

Han skal bringes til lidt efter lidt at være den Eneste, der snakker med." 
Idag forlanges der blot, at Arbejderen skal lystre - og i det hele taget opf $ø$ re sig som en Specialmaskine:

„Men efterhaanden vil hans Stemme og Røst blive saa stærk, at den bliver den raadende, den dominerende. Og det er just det, den skal og bør.“

Skønt E. Jensens konkrete forslag er delvis illusorisk, rummer artiklen $i$ sin analyse og i sit perspektiv en radikal socialismeopfattelse, der (desværre) er temmelig enestående $i$ arbejderbevægelsens daværende kulturdebat.

\section{Det ,anarkistiske” synspunkt}

Dette tredje synspunkt kommer bl.a. til udtryk i nogle foredrag, artikler og digte af Nex $\varnothing$ i perioden 1904-08. Steincke, Iversen og Jensen var for så vidt enige om, at oplysning og kamp for udvikling af bestemte kulturformer var nyttige, meningsfulde opgaver for arbejderbevægelsen. Uenigheden gjaldt oplysningens og kulturkampens former, indhold og perspektiv. Det „anarkistiske“ synspunkt rummer derimod en total afvisning af enhver form for oplysnings- og kulturarbejde. Sådanne aktiviteter kan kun fungere som hæmsko for revolutionen. I artiklen Det røde Flag (trykt i Verdensspejlet 1905), der er skrevet under indtryk af den russiske 1905-revolution, stiller Nex $\varnothing$ f $\varnothing$ lgende diagnose:

„Et Folk som det danske tænker overhovedet ikke; det ræsonnerer historisk. Alle dets Samfundslag har været i st $\varnothing$ rre eller mindre Berøring med Historien og al Historie er $\mathrm{i}$ sin Rod reaktionær. De, der har vist os et Glimt af Fremtiden, har altid været Mændene uden Stamtavle; de, der med et Tag endevender Begreberne var de Umælende, idet de fik Liv, den uhildede Almue i det $\emptyset_{j}$ jeblik, den traadte frem i Dagen.“ (Taler og Artikler II, p. 8)

Ogsaa i resten af Europa har folkene forskrevet sig til den saakaldte dannelse, historien og den ubrudte udvikling. Det er derimod „det stakkels reaktionære, forkuede, pjaltede Rusland“, det nye og uhørte skal komme fra: 
„Der er endnu Samfundslag, som befinder sig saa dybt nede, at de ikke kan akklimatisere sig men maa vove det store Spring mod Lyset eller omkomme.“ (ibid).

Kun den ubesmittede „natur“ kan gennemf $\varnothing$ re revolutionen, „kulturen“ er under alle forhold et undertrykkelsesinstrument.

I foredraget Egteskab og Fri Kcerlighed (holdt i Studentersamfundet 1906) anlægges det samme synspunkt på ægteskabet. Nexø slår fast, at „Det kapitalistiske Samfund har sit bedste Værn i Ægteskabet og sin Rugeplads under den fimsede Dyne Hjemmet som Regel er“.

Talen slutter:

„Slaa det bestaaende i Stykker, skab det Kaos som pæne Mennesker er saa bange for, netop fordi det er saa nødvendigt. Nye Former bliver aldrig til ved Forslag fra Enkeltmand. Deres Forudsætning er det kaotiske, den fuldstændige Mangel paa hæmmende Overlevering.

Lad enhver handle efter sit eget Hjærtes inderste Tilskyndelse, og den Samlivsform skal nok vælge sig ud og sejre som er den sundeste.“ (op.cit., p. 24).

\section{Konklusion}

At det næsten kun var den "faglærte“ form for arbejderkultur, der dannede udgangspunkt for den organiserede arbejderkultur bet $\varnothing \mathrm{d}$ en alvorlig begrænsning for denne. På trods af en imponerende række af aktiviteter, som alle har en positiv og lærerig side, var arbejderbevægelsens kulturpolitik derfor splittet og

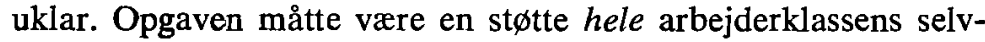
bevidsthed og selvaktivitet. Ikke at integrere sig - og heller ikke at isolere sig - men udvikle en aktiv modkultur med et perspektiv for en socialistisk magtovertagelse. Herbert Iversen og E. Jensen er dem, der ligger en sådan forståelse nærmest.

Til slut et par ord om hvilken funktion et forskningsarbejde, som det her skitserede kan have: Jeg ser det som min og mine kollegers opgave også at formidle erfaringer fra den undertrykte kulturtradition, som er arbejderklassens. Universiteterne har 
været toppen på kransekagen i et uddannelses- og kultursystem, der har fortrængt og undertrykt arbejderklassens såvel som andre undertrykte klasser og lags historie, kultur og erfaringer. Det er nu på tide med en smule mere objektivitet $i$ de humanistiske videnskaber.

Om en formidling af sådanne erfaringer også kan være medvirkende til udviklingen af en ny kulturel selvbevidsthed $i$ arbejderklassen, afhænger af så meget. Hovedspørgsmålet er, om den samfundsmæssige og politiske udvikling vil gøre det $\varnothing$ nskeligt, ja nødvendigt for arbejderklassen at udfolde en sådan kulturel selvbevidsthed og selvaktivitet. Så skal det nok komme.

Under alle omstændigheder: historiske erfaringer - positive og negative - er ikke noget dødt og fortidigt. Det er heller ikke noget man skal fors $\varnothing$ ge at kopiere. Det er derimod noget man skal lære af.

\section{Efterskrift}

\section{Kommunikationssammenhang}

Den foranstående tekst er manuskriptet til et foredrag, der blev holdt som led i den fortløbende foredragsserie „AUC-forelæsninger", hvor lærere ved AUC kan formidle deres forskning til en bredere offentlighed end den universitære. Teksten er naturligvis præget af denne formidlingssammenhæng. Den er introducerende, sprogligt elementær og umiddelbar. Længere citater med "spontan" underholdnings- og oplysningsværdi medtages. Præcise kildereferencer og litteraturhenvisninger mangler for det meste. Visse områder behandles yderst summarisk, idet hovedvægten lægges på områder som sjældent tages op eller som er indhyllet $i$ en tåge af fejlopfattelser (f.eks. familieformerne).

Med disse forbehold, med den vedføjede litteraturliste (som dog langtfra er „komplet“) og med de efterfølgende præciseringer kan det dog nok have en funktion at trykke teksten i et tidsskrift - som det den er: en introducerende oversigt over et væsentligt emne. 


\section{Forskningssammenhang}

Foredraget indgår $i$ en større arbejdsmæssig sammenhæng. Nogle af dets emner er langt bredere og mere dybtgående behandlet i min bog Pelle Erobreren. En historisk analyse (Vinten 1975) og mit antologi-bidrag Almueradikalismen og det revolutionare moderskab. En analyse af Martin Andersen Nexф: Ditte Menneskebarn (i Analyser af danske romaner II, Borgen 1977). Endelig er Gunhild Agger og jeg ved at færdiggøre en større bog med samme emne som foredraget, Arbejderkultur I (ca. 1870-1924), med indledning, tekstudvalg og tekstkommentarer. (Bogen, som er det fø̆rste af tre bind, udkommer på forlaget Medusa; andet bind (1924-48), skrevet og redigeret af Ib Bondebjerg og Olav Harsløf, er under trykning).

\section{De proletariske familieformer}

I forbindelse med afsnittet om de to familieformer kan det måske være nyttigt at præcisere dets indirekte polemiske sigte mod en hel tradition inden for marxistisk orienteret „familiesociologi“. I denne tradition - f.eks. repræsenteret af Petra Milhoffer: Familie og klasse (Rhodos, Kbh. 1975), Lena Dalgaard: Den proletariske families konstituering og udvikling under kapitalismen (Arhus 1974) og Ulf Hedetoft: Reproduktion og bevidstdannelse $i$ arbejderfamilien (Teori og klassekamp 1-2, 1976) arbejdes der ud fra en almen forestilling om ,arbejderfamilien“. Således tilsløres ikke mindst de store lagspecifikke forskelle som lige fra den internationale arbejderklasses konstituering til idag har præget de proletariske familieformer. Disse forskelle er faktisk et internationalt udbredt fænomen, men naturligvis er de igen specificeret af de enkelte nationale arbejderklassers historiske særudviklinger.

Almene spekulationer over "den proletariske familie“ (i de nævnte tilfælde præget af et kapitallogisk udgangspunkt) kan kun blive historisk fejlagtige og politisk-strategisk katastrofale. I kortfattet form demonstrerer foredraget bl.a. dette på den givne periode.

Det er dog også væsentligt at præcisere en afgrænsning over for en anden tendens, der er mest markant udformet $i$ Karl 
Heinz Roth: Den „anden“ arbejderbevagelse (GMT 1976), men som også synes at komme til udtryk i visse af Peter Brückners skrifter. Denne tendens tager - med korrekt udgangspunkt i en konstatering af de dybtgående modsætninger (ikke mindst i familieformer og socialisationsomstændigheder) mellem arbejderklassens „faglærte“, socialt stabile lag på den ene side og de „ufaglærte“, „randgrupperne“ på den anden - éntydigt stilling for de „ufaglærte“ og pjalteproletariske lag, mens de omvendt stempler de "faglærte“ som en blot og bar hæmsko for en revolutionær udvikling. En sådan opfattelse, der udnævner en del af arbejderklassen til det revolutionære subjekt, er omtrent lige så katastrofal som den førnæunte seen bort fra reelle forskelle og modsætninger. Begge tendenser umuligg $ø \mathrm{r}$ en virkelig kamp mod splittelserne $i$ arbejderklassen.

\section{K. K. Steincke og Herbert Iversen}

Steincke og Iversen behandles i foredraget blot som repræsentanter for "synspunkter" $i$ den datidige kulturdebat inden for den danske arbejderbevægelse. En egentlig politisk helhedsanalyse af deres indlæg var det under de foreliggende omstændigheder umuligt at foretage. Jeg skal kort skitsere nogle enkelte af de manglende elementer til en sådan analyse.

Steinckes kulturbetragtninger må for det første ses på baggrund af de specifikke omstændigheder omkring den danske arbejderklasses tilblivelse og udvikling: eksistensen af et stort og usædvanlig velorganiseret og ideologisk offensivt agrart småborgerskab, der uundgåeligt måtte præge arbejderklassen med småborgerlige normer og forestillinger. Den småborgerlige indflydelse overdeterminerer således modsætningen mellem „faglærte“ og "ufaglærte“. For det andet må Steincke ses som et dansk udtryk for den revisionistiske strømning i Anden Internationale, hvis hovedrepræsentant var Eduard Bernstein. I årene op til Første Verdenskrig skærpedes kampen mellem den bernstein'ske revisionisme og den kautskyanske centrisme også i det danske socialdemokrati. På det programmatiske område sejrede den sidstnævnte tendens foreløbig, idet partiet i 1913 vedtog et venstrecentristisk, marxistisk præget program. Det var folk som Gustav Bang og Gerson Trier, der stod for program- 
mets udformning. I det praktisk-politiske arbejde havde revisionistiske synspunkter som Steinckes imidlertid medvind. Dette blev især tydeligt efter krigsudbruddet, f.eks. da Stauning i 1916 indtrådte som „kontrolminister“ $i$ en borgerlig regering.

Herbert Iversen fremstår i foredraget som det positive modstykke til Steincke. Det er for så vidt korrekt nok, men dermed være ikke sagt at Iversens indlæg er frit for alvorlige historiske begrænsninger. Som de fleste andre, der dengang søgte at formulere en marxistisk klassekampslinje, er Iversen dybt præget af Anden Internationales kautskyanske marxisme, der ( $i$ en vis overensstemmelse med Engels' senere skrifter) er naturvidenskabsfikseret og tenderer $i$ retning af en positivistisk determinisme. Den deterministiske og naturvidenskabsfikserede tendens medvirker til at sløre en række af Iversens vurderinger og fremkalder en række modsætninger $\mathrm{i}$ hans fors $\emptyset \mathrm{g}$ på at udvikle en kulturpolitisk linje: skæv vurdering af socialdemokratiets magtposition, modsætning mellem den deterministiske tendens og fordringen om en aktiv kulturpolitisk indsats.

\section{Andre mangler}

Kulturdebatterne $\mathrm{i}$ arbejderbevægelsen henimod slutningen af og efter F $\phi$ rste Verdenskrig er overhovedet ikke taget op i foredraget. Her sker en vis internationalisering af debatten $i$ forbindelse med en udvikling af en særlig radikal strømning. Denne kommer bl.a. til udtryk $\mathrm{i}$ tidsskriftet Bålet (f.eks. i artikler af Bertel Budtz Müller), i Chr. Christensens angreb på Georg Brandes og i Nexøs litterære og publicistiske arbejder. Strømningen har flere berøringspunkter med den russiske proletkultbevægelse, især dens moralistisk revolutionære aspekter med religiøse overtoner („Gudsopbygning“). Højskoletraditionen er den særlige danske forudsætning for en gunstig reception af denne revolutionære moralisme og religiøsitet som alternativ til Anden Internationales kompromitterede marxistiske determinisme. 


\section{Selektiv litteraturliste}

Bang, Gustav:

Bertolt, Oluf (red):

Bomholt, Julius:

Bomholt, Julius:

Bomholt, Julius:

Bomholt, Julius:

Bomholt, Julius:

Bomholt, Julius:

Brückner, Peter:

Brückner, Peter og Ricke, Gabriele:

Christensen, Chr.:

Christensen, Chr.:

Christensen, Mikkel:

Emmerich, Wolfgang:
(1915) Arbejderklassens Liv og dens Kamp I-II, København.

(1925) Tre danske Arbejderes Livserindringer, K $\varnothing$ benhavn.

(1954) På vej til livet, København.

(1956) Vinterlys, København.

(1956) Himmerigs d $\phi r$, København.

(1957) Svalerne, København.

(1958) Dфgnflue og evighed, Kфbenhavn.

(1947) Et jydsk Arbejderhjem, i Danske Hiem ved Aarhundredskiftet I (red. af Povl Bagge), København.

(1974) Kapitalismens socialpsykolo$g i$, København.

(1975) Om den astetiske opdragelse af menneskene $i$ arbejderbevagelsen, i poetik 25, Kbh., på tysk i Das Unvermögen der Realität, Berlin 1974.

(1961) En rabarberdreng vokser op, København.

(1962) Bondeknold og rabarberdreng, København.

(1967) Min lille verden, København.

(1974- Proletarische Lebensläufe.

75) Autobiographische Dokumente zur Entstehung der Zweiten Kultur in Deutsch- 
Hansen, Anton:

Hansen, Oskar:

Hauge, C. N.:

Hedebol, Peder:

Meyer, A. C.:

Nex $\varnothing$, Martin Andersen (1969) Et lille Kra, København.

Nex $\varnothing$, Martin Andersen: (1969) Under aaben Himmel, K $\varnothing-$ benhavn.

Nexø, Martin Andersen: (1969) For Lud og koldt Vand, K $\varnothing-$ benhavn.

Nex $\varnothing$, Martin Andersen: (1969) Vejs Ende, København.

Petersen, Alfred og Jensen, Martin Evald:

Anonym redaktør:

Steensberg, Axel (red.): (1963- Dagligliv $i$ Danmark $i$ det

Tønnesen, Ejnar H.:

Ulriksen, Jørgen:

Williams, Raymond:
(1932) Raske Fjed. Ti arbejdende Kvinders Livserindringer, København.

64) nittende og tyvende århundrede $I-I I$, København.

(1930) Brydningsaar, København.

(1975) Arbejderfamiliers hverdag $i$ slutningen af 1800-tallet, $\mathrm{K} \varnothing-$ benhavn.

(1975) Trommehvirvler og kanonslag, København.

Culture and Society, London. 